\title{
IbM-Paguyuban Ibu-Ibu Kelurahan Tegalweru: Perancangan Desain Product label dan Trademark Oleh-oleh Khas Malang Produksi Desa Tegalweru Kabupaten Malang
}

\author{
Sultan Arif Rahmadianto ${ }^{1}$, Ruth Febriana Kesuma ${ }^{2}$, Yuyun Yuniati ${ }^{3}$ \\ ${ }^{1}$ Program Studi Desain Komunikasi Visual, 2,3 Program Studi Kimia \\ ${ }^{1}$ Fakultas Sains dan Teknologi, ${ }^{2,3}$ Universitas Ma Chung \\ e-mail: ${ }^{3}$ yuyun.yuniati@machung.ac.id
}

\begin{abstract}
Abstrak
Program pemberdayaan masyarakat ini bertujuan untuk meningkatkan omset penjualan produk olahan oleh-oleh khas Malang yang diproduksi oleh paguyuban ibu-ibu Kelurahan Tegalweru, Kecamatan Dau, Kabupaten Malang melalui perancangan desain product label dan trademark. Strategi untuk mencapai tujuan tersebut adalah melalui program IbM yang meliputi dua kegiatan, yaitu (1) sosialisasi materi pengantar desain sebagai alat pemasaran produk yang efektif dan (2) perancangan desain product label dan trademark produk olahan oleh-oleh khas Malang. Sasaran program ini adalah paguyuban ibu-ibu di kelurahan Tegalweru, Dau, Malang. Kegiatan sosialisasi materi pengantar desain sebagai alat pemasaran produk yang efektif dilaksanakan dalam satu kali pertemuan dengan pimpinan paguyuban ibu-ibu dalam bentuk presentasi dan diskusi. Adapun kegiatan perancangan desain product label dan trademark dilaksanakan selama kurang lebih 6 bulan dalam bentuk program pendampingan. Keberhasilan program pengabdian masyarakat ini ditentukan berdasarkan peningkatan wawasan tentang desain sebagai alat pemasaran produk yang efektif dan peningkatan omset dari penjualan produk olahan oleh-oleh khas Malang. Hasilnya adalah meningkatnya pengetahuan dan ketrampilan dalam bidang pengemasan produk olahan oleh-oleh khas Malang yang lebih menarik dan adanya desain product label dan trademark sebagai identitas produk olahan oleh-oleh khas Malang yang lebih menarik. Hasil ini menggambarkan bahwa program pengabdian pada masyarakat paguyuban ibu-ibu Kelurahan Tegalweru efektif untuk meningkatkan omset penjualan produk olahan oleh-oleh khas Malang.
\end{abstract}

Kata kunci : pemberdayaan; paguyuban ibu-ibu; desain product label; dan trademark

\section{Abstract}

The Community Empowerment Program aims to improve sales turnover of Malang's unique food product that production by mothers groups in Tegalweru, Dau sub-district, Malang regency. Strategy to achieve these objectives with mothers groups empowerment program with two activities (1) provide design insight as effective marketing tools and (2) Design product label and trademark Malang's unique food product. Target mothers program groups Tegalweru, Dau, Malang. Design insight activities were held one time with mothers group leader through presentation and discussion then design product label and trademark activities held approximate 6 months through accompaniment program. The success of the community service program is assessed on increased knowledge about design as effective marketing tools and increased sales turnover of Malang's unique food product. The results are increased knowledge and skills in design scope and there were product label and trademark design as the identity of Malang's unique food product that more interesting. These results illustrate the community service program in mothers groups were effective for increased sales turnover of Malang's unique food product.

Keywords: empowerment; mothers groups; design product label; and trademark 


\section{PENDAHULUAN}

Hasil bumi di Kabupaten Malang sangat berlimpah ruah. Panen hasil bumi terus dilakukan di Kabupaten Malang. Bergantian dari satu lolasi ke lokasi lain. Slogan tiada hari tanpa panen [3]. Kelurahan Tegalweru, Kecamatan Dau, Kabupaten Malang memiliki potensi besar untuk mengelola dan mengembangkannya untuk kemandirian dan kemajuhan desa. Melalui program desa yang diketuai oleh Ibu Lurah menginisiasi paguyuban ibu-ibu Kelurahan Tegalweru untuk mengolah potensi buah dan sayur seperti: pisang, kedelai, singkong dan lainnya menjadi produk olahan oleh-oleh khas Malang.

Produk pertama dan menjadi unggulan dari Kelurahan Tegalweru adalah kripik pisang. Produk kripik pisang ini sudah mulai dipasarkan di pasar Semarang [2]. Perkembangan produk yang sangat positif, memicu munculnya beberapa produk unggulan lainnya seperti kembang goyang, marning kedelai, dan kripik singkong. Produk olahan oleh-oleh khas Malang produksi Kelurahan Tegalweru ini memiliki keunggulan dibanding produk sejenis yaitu dari sisi memiliki rasa yang khas.

Permasalahan mendasar untuk sebuah usaha baru adalah belum memiliki alat pemasaran yang efektif dalam menjual produk khususnya dari sudut pandang desain. product label dan trademark adalah sebuah identitas visual khas yang dimiliki oleh sebuah usaha untuk menyampaikan informasi tentang produknya. Produk olahan oleh-oleh khas Malang produksi Kelurahan Tegalweru belum memiliki product label dan trademark yang baik sehingga ketika ini dibiarkan bisa mempengaruhi tingkat daya beli masyarakat terhadap produk tersebut.

Pelaku usaha dibidang produk olahan khas daerah khususnya Malang sangat banyak. Sehingga perlu adanya strategi khusus untuk mampu bersaing di pasar. Untuk bisa menonjol dan dikenal diantara produk sejenis selain dari keunggulan kualitas produk juga diperlukan sebuah alat bantu berupa identitas visual. Sebuah identitas visual memiliki peran yang mendukung terciptanya reputasi (image) dan mempermudah seseorang calon pembeli (potential buyer) untuk mengenali (recognize) atau menyebutkan kembali (recall) suatu identitas yang menjadi bagian dari suatu kategori produk [1].

Program pemberdayaan masyarakat ini bertujuan untuk meningkatkan omset penjualan produk olahan oleh-oleh khas Malang yang diproduksi oleh paguyuban ibu-ibu Kelurahan Tegalweru, Kecamatan Dau, Kabupaten Malang melalui perancangan desain product label dan trademark. Strategi untuk mencapai tujuan tersebut adalah melalui program IbM yang meliputi dua kegiatan, yaitu:

1. Presentasi dengan topik: desain sebagai alat pemasaran produk yang efektif.

2. Perancangan desain product label dan trademark produk olahan oleh-oleh khas Malang.

\section{SUMBER INSPIRASI}

Beberapa permasalahan yang telah diindentifikasi dirumuskan permasalahan utama dalam program pengabdian pada masyarakat paguyuban ibu-ibu Kelurahan Tegalweru sebagai berikut:

1. Masyarakat minim ilmu dan wawasan tentang desain sebagai alat pemasaran yang efektif dalam penjualan produk.

2. Masyarakat minim pengalaman dalam proses penciptan product label dan trademark yang menarik sehingga mampu menarik calon pembeli untuk membeli produk.

\section{METODE KEGIATAN}

Pelaksanakan program IbM ini terbagi dalam dua kegiatan, yakni pelatihan dan program pendampingan perancangan desain product label dan trademark. Uraian dua kegiatan tersebut sebagai berikut:

1. Pelatihan dilaksanakan selama satu hari. Total waktu pelatihan adalah delapan jam efektif. Mitra menentukan perwakilan dan dipilih ketua paguyuban ibu-ibu Kelurahan Tegalweru untuk 
mengikuti pelatihan ini. Pelatihan dilaksanakan dirumah ketua paguyuban. Materi utama pelatihan adalah desain sebagai alat pemasaran produk yang efektif. Ketua paguyuban tersebut kemudian ditugaskan mensosialisasikan ke anggota lainnya.

2. Program pendampingan perancangan desain product label dan trademark mengadopsi model perancangan branding identity [4] yaitu: (1) identifikasi masalah (2) sintesis (3) desain (4) revisi (5) produksi. Program pendampingan ini dilaksanakan selama kurang lebih enam bulan. Selama program ini berlangsung posisi mitra adalah sebagai narasumber / klien terkait kebutuhan perancangan.

Partisipasi yang diberikan mitra berupa dukungan dan komitmen pelaksanaan kegiatan, yakni dengan menyediakan fasilitas tempat untuk pelaksanaan kegiatan. Dukungan mitra lainnya adalah pemilihan perwakilan sebagai peserta pelatihan. Instrumen yang digunakan pada program pengabdian kepada masyarakat ini meliputi (a) laptop (b) kamera (c) set alat tulis.

Lokasi kegiatan adalah di Kelurahan Tegalweru, Kecamatan Dau, Kabupaten Malang. Waktu pelaksanaan kegiatan adalah Maret sampai Oktober 2018 (dalam kurun waktu delapan bulan). Adapun durasi kegiatan pengabdian adalah selama kurun waktu delapan bulan yang terbagi dalam tiga tahap, yaitu (1) tahap sosialisasi, (2) tahap pelatihan, dan (3) tahap pendampingan. Evaluasi program pengabdian akan dilaksanakan dengan dua pendekatan sebagai berikut.

1. Evaluasi keberhasilan kegiatan pelatihan dilakukan dengan cara uji pengetahuan secara kualitatif dengan pertanyaan seputar pemanfaatan desain sebagai alat pemasaran.

2. Pertanyaan akan diberikan sebelum dan sesudah kegiatan serta pada akhir program. Kemauan investasi cetak/print label produk merupakan tingkatan keberhasilan dari pelatihan ini.

3. Evaluasi keberhasilan program pendampingan perancangan desain product label dan trademark dilakukan dengan melihat hasil dari desain product label dan trademark yang telah dicetak dan diimplementasikan pada setiap kemasan produk olahan oleh-oleh khas Malang produksi paguyuban ibu-ibu Kelurahan Tegalweru.

4. Keberlanjutan program akan tetap terjaga dengan adanya pengurus paguyuban yang telah terlatih. Hal ini dibuktikan dengan komitmen tertulis dari peserta pelatihan.

\section{KARYA UTAMA}

1. Pelatihan Wawasan Desain pada 19 Maret 2018.

2. Program pendampingan perancangan desain product label dan trademark.

\section{ULASAN KARYA}

\section{A. Kegiatan Pertama: Pelatihan Wawasan Desain pada 19 Maret 2018}

Kegiatan pertama berbentuk pelatihan. Pelatihan dilaksanakan selama satu hari. Pelatihan dilaksanakan di rumah ketua paguyuban ibu-ibu Kelurahan Tegalweru. Total waktu pelatihan adalah delapan jam efektif. Paguyuban ibu-ibu Kelurahan Tegalweru diwakili oleh Ketua pengurus untuk mengikuti pelatihan. Kegiatan dilakukan dengan metode presentasi oleh tim abdimas yang dilakukan dalam tiga tahap, yaitu (1) prakegiatan yang dilakukan dengan mengukur tingkat pengetahuan peserta tentang pemanfaatan desain sebagai alat pemasaran; (2) tahap pelaksanaan yang dilakukan dengan memberikan materi utama, yakni desain sebagai alat pemasaran yang efektif; dan (3) tahap evaluasi yang dilakukan dengan mengukur berhasilan pelatihan.

Dalam pelatihan tersebut disampaikan materi tentang desain product label dan trademark [5] meliputi: corporate identity, fungsi corporate identity, aplikasi corporate identity, komponen corporate identity, brand identity system. Desain pelatihan dengan pendekatan presentasi dan diskusi (Gambar 1) memudahkan peserta dalam memahami materi. 


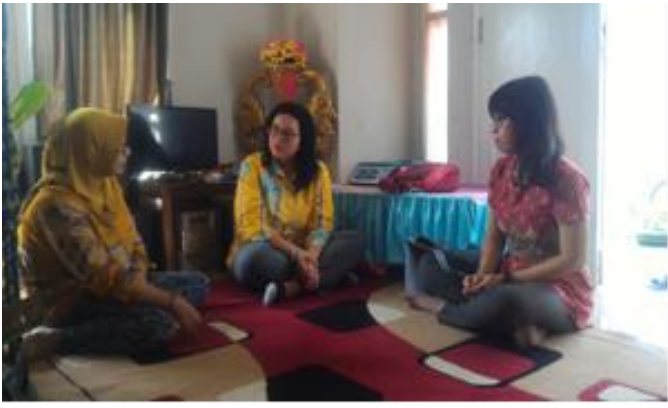

Gambar 1. Kegiatan Pelatihan paguyuban

Evaluasi keberhasilan kegiatan pelatihan dilakukan dengan cara uji pengetahuan secara kualitatif dengan pertanyaan seputar pemanfaatan desain sebagai alat pemasaran. Pertanyaan akan diberikan sebelum dan sesudah kegiatan serta pada akhir program. Kemauan investasi cetak/print label produk merupakan tingkatan keberhasilan dari pelatihan ini.

Hasilnya paguyupan ibu-ibu Kelurahan Tegalweru memiliki wawasan yang cukup dan memiliki presepsi bahwa pemanfaatan desain sebagai alat penjualan produk sangat penting dan diakhiri dengan kemauan untuk berinvestasi mencetak/print label produk baru pada seluruh produk olahan oleh-oleh khas Malang produksi paguyuban ibu-ibu Kelurahan Tegalweru.

\section{B. Kegiatan Kedua: Program pendampingan} perancangan desain product label dan trademark

Kegiatan kedua dilaksanakan selama kurang lebih enam bulan yaitu sejak awal bulan April sampai akhir September 2018. Program pendampingan perancangan desain product label dan trademark mengadopsi model perancangan branding identity Wheller (2009) yaitu: (1) identifikasi masalah (2) sintesis (3) desain (4) revisi (5) produksi. Selama program ini berlangsung posisi mitra adalah sebagai narasumber/klien terkait kebutuhan perancangan. Berikut ini adalah hasilnya:

\section{Identifikasi masalah}

Tahap ini adalah tahap penggalian informasi melalui teknik wawancara (Gambar 2) untuk mengetahui profil produk sebagai dasar dalam konsep visual yang akan digunakan dan pada tahap ini ditemukan nama merek yaitu Ibu Lurah.

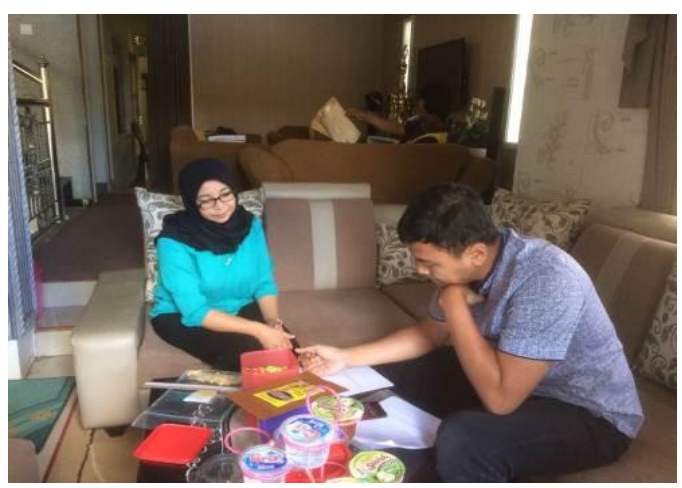

Gambar 2. Wawancara dengan ketua paguyuban

\section{Sintesis}

Tahap ini adalah hasil analisis data dalam bentuk brief Desain meliputi desain untuk cemilan kripik pisang kembang goyang, marning kedelai, dan kripik singkong. Secara garis besar konsep desain yang akan diterapkan khususnya untuk label kemasan adalah bergaya tradisional dengan memasukkan elemen visual batik. Dan untuk desain merek atau trademark mengusung tema seorang istri dari lurah yang menggunakan atribut Lurah yaitu menggunakan baju kebaya.

\section{Desain}

Tahap ini adalah adalah proses desain berdasarkan konsep yang telah didapatkan sebelumnya.

\section{a.Desain Trademark}

Untuk konsep yang pertama adalah konsep desain trademark. Proses ini diawali dengan mencari referensi (Gambar 3) sebanyak mungkin tentang bentuk trademark yang sesuai dengan konsep.
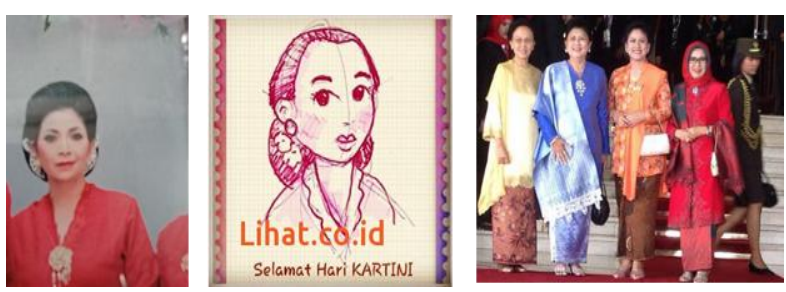

Gambar 3. Referensi sosok Ibu Lurah

Setelah mendapatkan konsep visual dari Ibu lurah selanjutnya adalah proses sketsa dan finalisasi bentuk 
(Gambar 4) diakhiri desain final menggunakan bantuan komputer (Gambar 5).

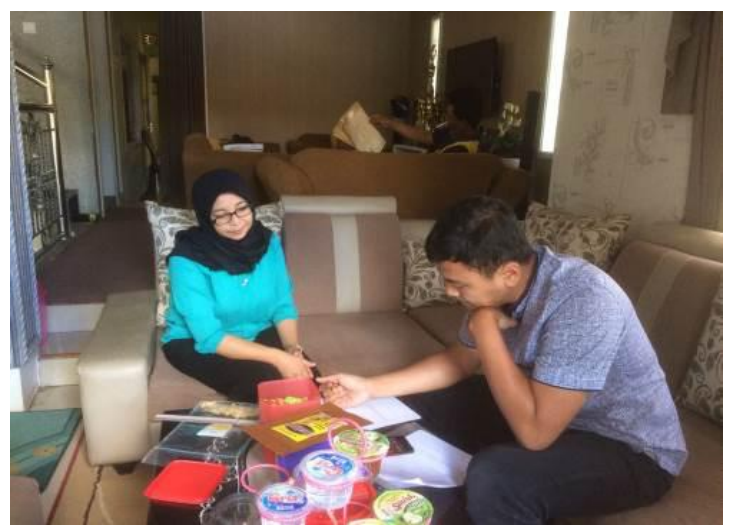

Gambar 4. Proses desain manual Trademark Bu Lurah

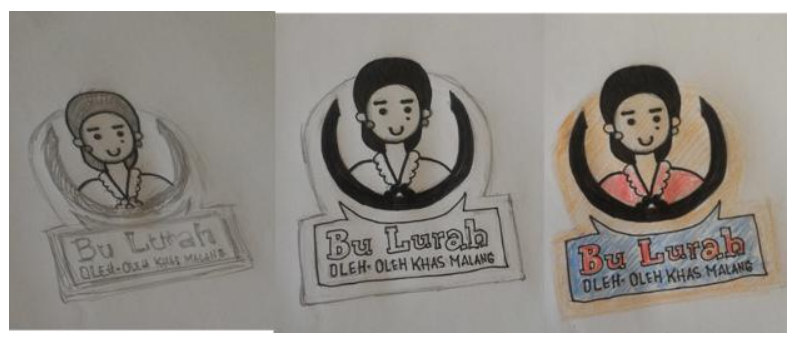

Gambar 5. Desain Trademark Bu Lurah

(Gambar 5) Merupakan desain final dari merek Bu Lurah dengan mengedepankan sosok Ibu Lurah yang khas dengan kebayanya dan perpaduan warna yang menarik.

\section{b.Desain Label Kemasan}

Desain label kemasan dari Bu Lurah menggunakan konsep visual tradisional dan menggunakan visual batik sebagai backgroundnya konsep ini merupakan pemikiran dari pemilik dari merek $\mathrm{Bu}$ Lurah untuk menonjolkan filosofi pelestarial budaya lokal di masa modern. Sehingga secara visual kesan tradisional menjadi poin utama. Dalam desain label kemasan ini ada informasi yang wajib harus ada sebagai standar desain kemasan yang telah diimplementasi secara baik meliputi: nama merek, nama produk, jenis produk, berat netto, PIRT, expire date, komposisi, dan keterangan produsen. Untuk lebih jelasnya dapat melihat (Gambar $6)$.

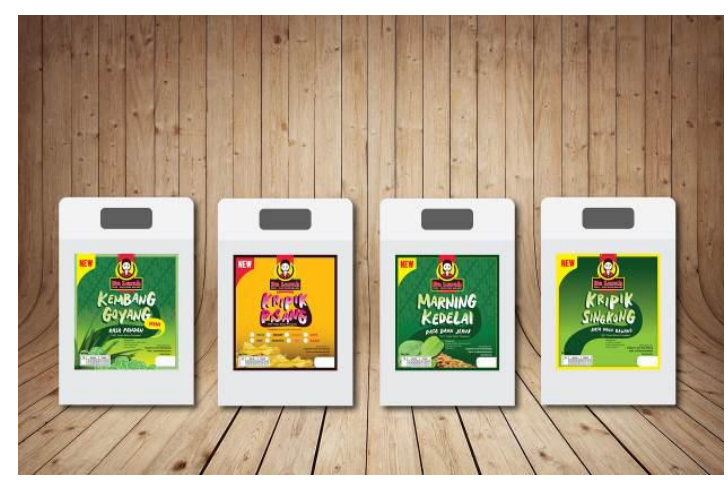

Gambar 6. Desain Final label kemasan Bu Lurah

\section{c. Revisi}

Untuk evaluasi dari desain yang dibuat setelah dilihat oleh pemilik merek "Bu Lurah" adalah Sangat luar biasa bagus namun ada beberapa koreksi yaitu untuk trademark merek itu ada perubahan. Untuk desain awal merek bu lurah menggunakan atribut seragam lurah dan minta direvisi menggunakan attribut kebaya untuk lebih menonjolkan sisi tradisional kemudian untuk kata oleh-oleh khas malang bisa agak diperbesar. Lihat (Gambar 7).

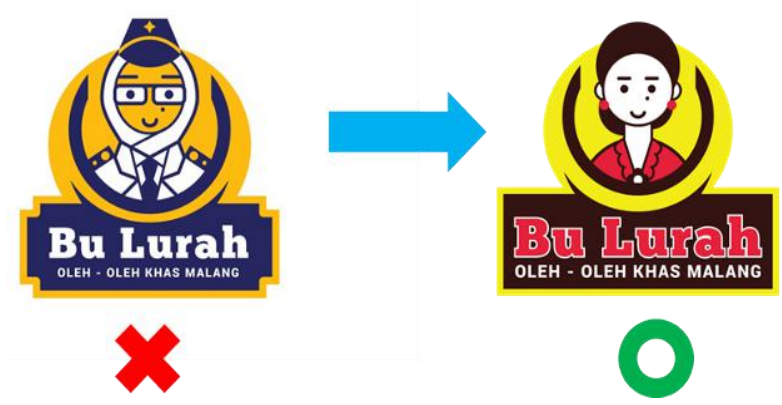

Gambar 7. Revisi desain Trademark "Bu Lurah"

\section{d.Produksi}

Setelah desain telah disetujui tahap terakhir adalah produksi masal dari desain product label kemasan tersebut dan memberikannya softfile data kepada pemilik trademark untuk bisa diproduksi sewaktu-waktu (Gambar 8). 


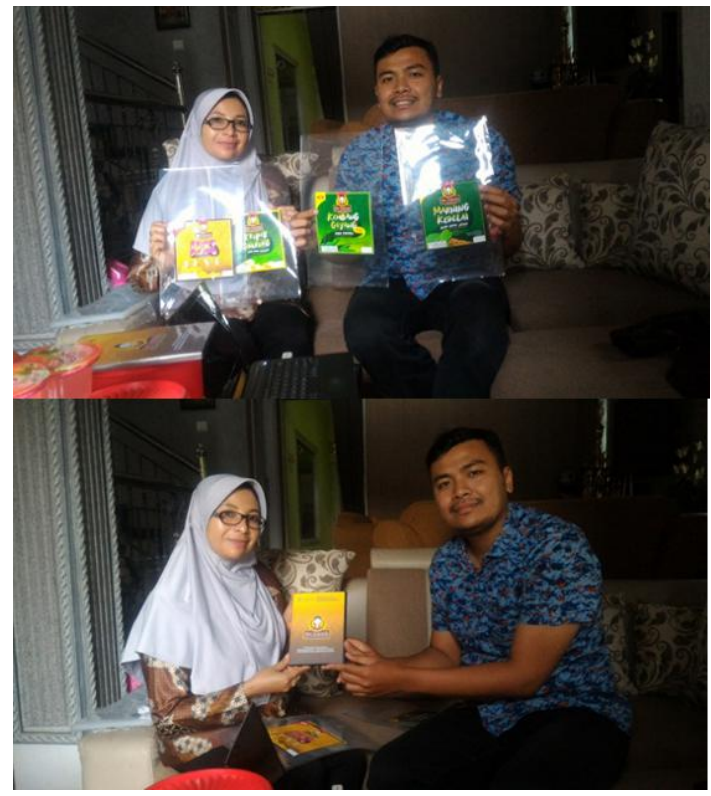

Gambar 8. Penyerahan cetak dan softfile desain label kemasan "Bu lurah"

Evaluasi keberhasilan program pendampingan perancangan desain product label dan trademark dilakukan dengan melihat hasil dari desain product label dan trademark yang telah dicetak dan diimplementasikan pada setiap kemasan produk olahan oleh-oleh khas Malang produksi paguyuban ibu-ibu Tegalweru.

Hasilnya paguyupan ibu-ibu Kelurahan Tegalweru telah memproduksi masal label produk dan telah diimplementasikan diseluruh produk olahan oleh-oleh khas Malang. Pada tahap terakhir dilakukan kesepakatan dan komitmen mitra untuk secara kontinu melaksanakan penerapan desain sebagai alat penjualan produk mereka.

\section{KESIMPULAN}

Berdasarkan pelaksanaan program pengabdian kepada masyarakat dapat disimpulkan bahwa tujuan dari program ini tercapai diantaranya meningkatkan pengetahuan masyarakat, khususnya paguyuban ibu-ibu Kelurahan Tegalweru tentang desain sebagai alat penjualan produk yang efektif dan Paguyuban ibu-ibu Kelurahan Tegalweru dengan didampingi oleh tim pengabdian telah berhasil menghasilkan desain product label dan trademark.

\section{DAMPAK DAN MANFAAT KEGIATAN}

Dampak dan manfaat dalam kegiatan ini adalah terwujud komitmen untuk melaksanakan penerapan desain sebagai alat penjualan produk mereka secara mandiri. Kegiatan ini diharapkan dapat berdampak pada peningkatan omset penjualan produk olahan oleh-oleh khas Malang diproduksi oleh paguyuban ibu-ibu Kelurahan Tegalweru, Kecamatan Dau, Kabupaten Malang.

\section{DAFTAR PUSTAKA}

[1] Rahmadianto, Sultan Arif, "Perancangan Corporate Identity S1 Desain Komunikasi Visual Universitas Ma Chung sebagai Upaya Meningkatkan Brand Awarenes" Journal of Visual Communication Desingn. Vol.IV (2016): 284.

[2] “UKM Malang Lirik Pasar Semarang,” RADAR, 12 February 2017, sec. D3.

[3] BALITKABI." Panen Melimpah di Kabupaten Malang. $\quad 15 \quad$ January 2018. $<$ http://balitkabi.litbang.pertanian.go.id/upsus/panen -melimpah-di-kabupaten-malang/>. (diakses pada 03 September 2018).

[4] Wheeler, Alina. Design Brand Identity. Willey and Sons inc. US, 2009.

[5] Abasov, Mike. Basic Component of Your Corporate Identity. Marketing before funding. US , 2016.

\section{PENGHARGAAN}

Tim pengabdi mengucapkan terima kasih atas kesempatan yang diberikan oleh Universitas Ma Chung melalui pemberian dana dalam Skema Ma Chung Abdimas Grant (MAG) dengan kontrak Nomor 027/MACHUNG/LPPM-MAG-IbM/II/20. 